\title{
Endothelin-converting-enzyme 1 inhibition and CGRP receptor recycling in human coronary and middle meningeal arteries
}

\author{
S Labruijere ${ }^{1 *}$, R De Vries $^{1}$, AHJ Danser ${ }^{1}$, GS Cottrell ${ }^{2}$, A MaassenVanDenBrink $^{1}$ \\ From The European Headache and Migraine Trust International Congress \\ London, UK. 20-23 September 2012
}

\begin{abstract}
Although best known for its role in the conversion of big endothelin to endothelin-1, endothelin-converting enzyme 1 (ECE-1) also regulates the resensitization of certain neuropeptide receptors, including the receptor for calcitonin gene-related peptide (CGRP) (Padilla et al., 2007). We investigated the role of ECE-1 in the resensitization of responses to CGRP in human coronary (HCA) and middle meningeal (HMA) arteries using the potent and selective ECE-1 inhibitor, SM-19712. Segments of HCA (Ø 0.5-1 $\mathrm{mm})$ and HMA (Ø $0.5-1 \mathrm{~mm})$ were mounted in organ baths and concentration response curves (CRCs) to CGRP were constructed in the absence or presence of the ECE-1 inhibitor SM-19712. After the first CRC to CGRP the segments were washed and after 30-45 minutes a second $\mathrm{CRC}$ was constructed in the absence or presence of SM19712 to investigate ECE-1-dependent CGRP resensitization. Furthermore, CRCs to big endothelin were constructed in the presence or absence of SM-19712. In both HCA and HMA, no differences were seen between the initial responses to CGRP in the absence or presence of SM-19712 (HCA $\mathrm{E}_{\max +\mathrm{SM} 19712}$ 94 $\pm 8 \%, \mathrm{E}_{\max -\mathrm{SM} 19712}$ $93 \pm 5 \% ; \mathrm{pEC}_{50+\mathrm{SM} 19712} 9.1 \pm 0.2, \mathrm{pEC}_{50-\mathrm{SM} 19712} 9.2 \pm 0.1$; HMA $E_{\max +S M 19712} 72 \pm 7 \%, \mathrm{E}_{\max -S M 19712} 59 \pm 7 \%$; pEC 50 +SM19712 8.5 $\pm 0.4, \mathrm{pEC}_{50 \text {-SM19712 }} 8.1 \pm 0.8$ ), as well as between the second CRCs to CGRP in the absence or presence of SM-19712 (HCA $\mathrm{E}_{\max +\mathrm{SM} 19712} 110 \pm 13 \%$, $\mathrm{E}_{\max -}$ SM19712 $78 \pm 22 \%$; $\mathrm{pEC}_{50+\mathrm{SM} 19712} 7.5 \pm 0.5, \mathrm{pEC} \mathrm{C}_{50-\mathrm{SM} 19712}$ 7.9 \pm 0.01 ; HMA $\mathrm{E}_{\max +\mathrm{SM} 19712} 38 \pm 13 \%, \mathrm{E}_{\max -\mathrm{SM} 19712}$ $44 \pm 1 \% ; \mathrm{pEC}_{50+\mathrm{SM} 19712} 8.6 \pm 0.5, \mathrm{pEC} \mathrm{C}_{50-\mathrm{SM} 19712} 7.8 \pm 0.9$ ). Furthermore, contractions to big endothelin were not different in the absence or presence of SM-19712 in either HCA $\left(E_{\max +\mathrm{SM} 19712} 118 \pm 14 \%, \mathrm{E}_{\max -\mathrm{SM} 19712} 115 \pm 32 \%\right.$;
\end{abstract}

Full list of author information is available at the end of the article
$\left.\mathrm{pEC}_{50+\mathrm{SM} 19712} 6.0 \pm 0.5, \mathrm{pEC} 50-\mathrm{SM} 197126.9 \pm 0.2\right)$ or HMA $\left(\mathrm{E}_{\max +\mathrm{SM} 19712} 121 \pm 1 \%, \mathrm{E}_{\max -\mathrm{SM} 19712} 147 \pm 19 \%\right.$; $\mathrm{pEC}_{50-}$

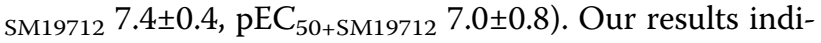
cate that ECE-1 does not regulate the resensitization of CGRP responses in HCA and HMA.

\section{Author details}

Published: 21 February 2013

\section{Reference}

1. Padilla $B E$, et al: Endothelin-converting enzyme-1 regulates endosomal sorting of calcitonin receptor-like receptor and beta-arrestins. J Cell Biol 2007, 179(5):981-97.

doi:10.1186/1129-2377-14-S1-P95

Cite this article as: Labruijere et al: Endothelin-converting-enzyme 1 inhibition and CGRP receptor recycling in human coronary and middle meningeal arteries. The Journal of Headache and Pain 2013 14(Suppl 1): P95.

\section{SpringerOpen ${ }^{\odot}$}

( 2013 Labruijere et al; licensee Springer. This is an Open Access article distributed under the terms of the Creative Commons Attribution License (http://creativecommons.org/licenses/by/2.0), which permits unrestricted use, distribution, and reproduction in any medium, provided the original work is properly cited.
Submit your manuscript to a SpringerOpen ${ }^{\circ}$ journal and benefit from:

- Convenient online submission

- Rigorous peer review

- Immediate publication on acceptance

- Open access: articles freely available online

- High visibility within the field

Retaining the copyright to your article

Submit your next manuscript at $>$ springeropen.com 